\title{
ERRATUM
}

Corine P. Kruiswijk • Trudi Hermsen • Joost van Heerwaarden • Brian Dixon • Huub F. J. Savelkoul · René J. M. Stet

\section{Major histocompatibility genes in the Lake Tana African large barb species flock: evidence for complete partitioning of class II $B$, but not class I, genes among different species}

Published online: 11 May 2005

(C) Springer-Verlag 2005

The online version of the original article can be found at http:// dx.doi.org/10.1007/s00251-005-0767-5

C. P. Kruiswijk · T. Hermsen · J. van Heerwaarden

H. F. J. Savelkoul · R. J. M. Stet ( $\bowtie)$

Cell Biology and Immunology Group,

Wageningen Institute of Animal Sciences,

Wageningen University,

Marijkeweg 40,

6709 PG Wageningen, The Netherlands

e-mail: rene.stet@wur.nl

Tel.: +31-317-483922

Fax: +31-317-483955

B. Dixon

Department of Biology, University of Waterloo,

200 University Avenue West,

ONT, N2L 3G1, Canada

R. J. M. Stet

Scottish Fish Immunology Research Centre,

University of Aberdeen,

Zoology Building, Tillydrone Avenue,

Aberdeen, AB24 2TZ, Scotland, UK

\section{Immunogenetics (2005) 56:894-908}

The electronic supplementary material to this article was incomplete. Tables 1-3 are now available at $\mathrm{http}: / / \mathrm{dx}$.doi. org/10.1007/s00251-005-0767-5 